Article

\title{
Unravelling the Relative Contribution of Dissolved Carbon by the Red River to the Atchafalaya River
}

\author{
Yi-Jun Xu* (D) and Emily Marie DelDuco \\ School of Renewable Natural Resources, Louisiana State University Agricultural Center, Baton Rouge, LA 70803, \\ USA; edelduco19@gmail.com \\ * Correspondence: yjxu@lsu.edu; Tel.: +1-225-578-4168
}

Received: 15 August 2017; Accepted: 4 November 2017; Published: 8 November 2017

\begin{abstract}
The Atchafalaya River (AR), North America's largest swamp river, annually discharges a large volume of freshwater (nearly $200 \mathrm{~km}^{3}$ ), delivering $25 \%$ of the Mississippi River's (MR) flow and the entire Red River's (RR) flow into the Gulf of Mexico. Studies have reported higher levels of organic carbon in the AR's outlets compared to the MR's outlet, raising questions about local carbon sources. In this study, we investigated dissolved organic carbon (DOC) and dissolved inorganic carbon (DIC) inputs into the AR from the RR and MR using DOC and DIC concentrations, mass loading, and isotopic signature $\left(\delta^{13} \mathrm{C}\right)$ analyses. Monthly river water sampling was conducted in the MR and RR near their confluence where the AR is formed from May 2015 to May 2016. DIC concentrations in the RR were found to be only half of those found in the MR, while the RR's DOC concentrations were on average 1.8 times higher than those found in the MR. Based on the models developed for this study period, the RR's contribution to DIC mass loading in the AR represented 1.41 teragrams (Tg) (or, 29.7\%) of the total $4.76 \mathrm{Tg}$ DIC transported by both tributaries, while its contribution to DOC mass loading was disproportionately high, accounting for $1.74 \mathrm{Tg}$ of the $2.75 \mathrm{Tg}$ DOC (or, $63.2 \%$ of total DOC) entering the AR. Both $\delta^{13} \mathrm{C}_{\mathrm{DIC}}$ and $\delta^{13} \mathrm{C}_{\mathrm{DOC}}$ showed significantly more negative values in the RR than those found in the MR. Significant correlation between $\delta^{13} \mathrm{C}_{\mathrm{DIC}}$ and $\delta^{13} \mathrm{C}_{\mathrm{DOC}}$ isotope values in the RR indicated interrelation of dissolved carbon processing, which was not observable in the MR. These results strongly suggest that the RR is an extremely significant source of DOC to the AR, and thus the Gulf of Mexico, and additionally plays an important role in diluting the anthropogenically enhanced DIC fluxes of the MR.
\end{abstract}

Keywords: dissolved organic carbon; dissolved inorganic carbon; river biogeochemistry; river swamp; Atchafalaya River; Mississippi River

\section{Introduction}

The quantity and quality of carbon exported by rivers to coastal margins has important impacts on coastal and marine ecosystem health and functioning, and are important to the development of global carbon budgets [1,2]. Draining a total land area of approximately 3.2 million $\mathrm{km}^{2}$, the Mississippi River (MR) is one of the largest rivers in the world and plays an important role in global river carbon export [3-6]. The river has two main outlets to the Gulf of Mexico: the Mississippi River main stem (also known as the Lowermost Mississippi River), and the Atchafalaya River (AR) which also carries the total flow of the Red River (RR). Over the past three decades, on average, the MR annually discharged $474 \mathrm{~km}^{3}$ [7] and the AR discharged $199 \mathrm{~km}^{3}$ [8] of freshwater into the Northern Gulf of Mexico (NGOM), carrying large quantities of carbon to Louisiana's coastal margins. Due to these large inputs, the river plumes from the Mississippi-Atchafalaya River System (MARS) dominate biogeochemical cycling in the NGOM $[9,10]$. Inputs of anthropogenic riverine carbon may play a role in coastal ecosystem disruption; for example, organic matter exported by the MARS may contribute up 
to $23 \%$ of the $\mathrm{O}_{2}$ demand that is necessary for the perpetuation of seasonal severe hypoxic conditions in the Gulf of Mexico [11,12]. Though coastal systems have gained increasing recognition as influential components of global carbon budgets $[13,14]$, carbon dynamics in coastal regions such as the NGOM remain complicated and poorly characterized due to a lack of geographically specific estimates of carbon export [1], thus preventing integration into global carbon assessments. Though the MR has been relatively well studied, carbon constituents in the large and influential AR swamp-river basin remain poorly characterized.

The AR is often considered simply as a distributary of the MR, but the large and less anthropogenically impacted RR may have an important influence on both the quantity and quality of riverine dissolved inorganic carbon (DIC) and dissolved organic carbon (DOC) passing through the AR into the NGOM. The fraction of the Atchafalaya River's flow contributed by the RR can vary anywhere from $7 \%$ to $70 \%$ throughout a given year [15]. The waters of the AR therefore display large temporal variations in chemical composition according to the relative contributions of its tributaries. For example, a study on nitrate in this system concluded that although approximately one-third of the Atchafalaya River's average flow came from the RR, a nearly negligible 3\% of the AR's total mass load of nitrate was delivered by the RR [15]. This means that the RR has the capacity to play an important role in diluting the large loads of nutrients in the Atchafalaya [16] entering the NGOM from the agriculturally dominated Mississippi River watershed. The RR may also differ greatly from the diverted portion of the MR in terms of dissolved carbon mass constituents delivered to the AR. The potential effect of the RR on the MR's anthropogenically impacted DIC and DOC loads is therefore critically important to consider when evaluating the export of dissolved carbon from the MARS into coastal systems.

DOC in the MR has been demonstrated to be largely refractory, with only about $3 \%$ of DOC contributing to the labile carbon pool [17]. Measurements conducted in the Atchafalaya Bay and MR delta have indicated, however, that the AR carries higher concentrations of DOC, which has also been shown to be of higher quality than DOC in the MR [18]. It has been speculated that the higher DOC concentrations found in the AR are due to inputs of organic material from within the AR's floodplains [18], but the RR's potential importance as a source for this more labile organic material remains poorly investigated. Information regarding the differences in composition and the quality of carbon inputs from the RR and MR tributaries remains sorely lacking.

Riverine stable carbon isotope analysis describes the ratio of ${ }^{13} \mathrm{C} /{ }^{12} \mathrm{C}$ in a sample of water, which can be used to identify major sources of dissolved carbon as it interacts with the atmosphere, sediment, and biosphere; isotopic constraining of carbon sources and in-stream processing provides useful information regarding the quality of carbon constituents. Carbon originating, for example, from the atmosphere, plants using the $C_{4}$ pathway, plants using the $C_{3}$ pathway, carbonate weathering, algal production, and soil leachates, all have different isotopic signatures [19-23]. Within aquatic systems, the $\delta^{13} \mathrm{C}$ values of these terrestrially-derived carbon sources are further impacted by riverine biogeochemical processes; photosynthesis and atmospheric degassing preferentially remove ${ }^{12} \mathrm{C}$ [24], which leaves the remaining aquatic carbon pool enriched in ${ }^{13} \mathrm{C}$, resulting in a positive shift in $\delta^{13} \mathrm{C}$ values; meanwhile respiration processes contribute to ${ }^{13} \mathrm{C}$ uptake, and subsequently more negative isotope values [25]. Studying isotopic composition of dissolved carbon in the RR and MR outflows into the AR may provide useful insight into the potential sources and processes that are responsible for dissolved carbon constituents entering the Atchafalaya River Basin, reflecting water quality and ecological functioning.

This study aimed to determine the relative contribution of the Red River to dissolved carbon dynamics in the Atchafalaya River. Specifically, the study set out to (1) collect water samples and conduct in-situ measurements at locations near the confluence of the MR and RR over a 1-year period; (2) analyze riverine dissolved organic and inorganic carbon concentrations in and their mass loads of these tributaries to the Atchafalaya; and, (3) identify composition and source of dissolved organic and inorganic carbon with isotopic signature of $\delta^{13} \mathrm{C}$ at a wide range of flow conditions and relative 
discharge contributions by the Red River. The data collected in this study describes how the waters of the Atchafalaya River are compositionally affected, in terms of both quantity and quality of dissolved carbon constituents, by the relative chemical contributions of the Red River.

\section{Materials and Methods}

\subsection{Study Area}

This study was conducted near the confluence of the Red River and the Mississippi River at the Old River Control Structure (ORCS) in central Louisiana, USA (Figure 1). The $2189 \mathrm{~km}$ long Red River originates from northwestern Texas and flows eastward to Oklahoma and Arkansas and north Louisiana before joining the diverted water from the Mississippi to form the Atchafalaya River. The Red River drains $169,890 \mathrm{~km}^{2}$ of land, originating in a semiarid climate, passing through a wide variety of ecosystems, and encountering a subtropical humid environment, with annual precipitation reaching $1500 \mathrm{~mm}$ at its confluence in central Louisiana. The western portion of the river flows through areas that are composed of $40-60 \%$ rangeland and $30 \%$ cropland, while the eastern portion is $50 \%$ forested, $20 \%$ cropland, and only $10 \%$ pasture. The Red River Basin is thus very different than that of the Mississippi River Basin, which is predominately cropland (58\%) over its 3 million $\mathrm{km}^{2}$.

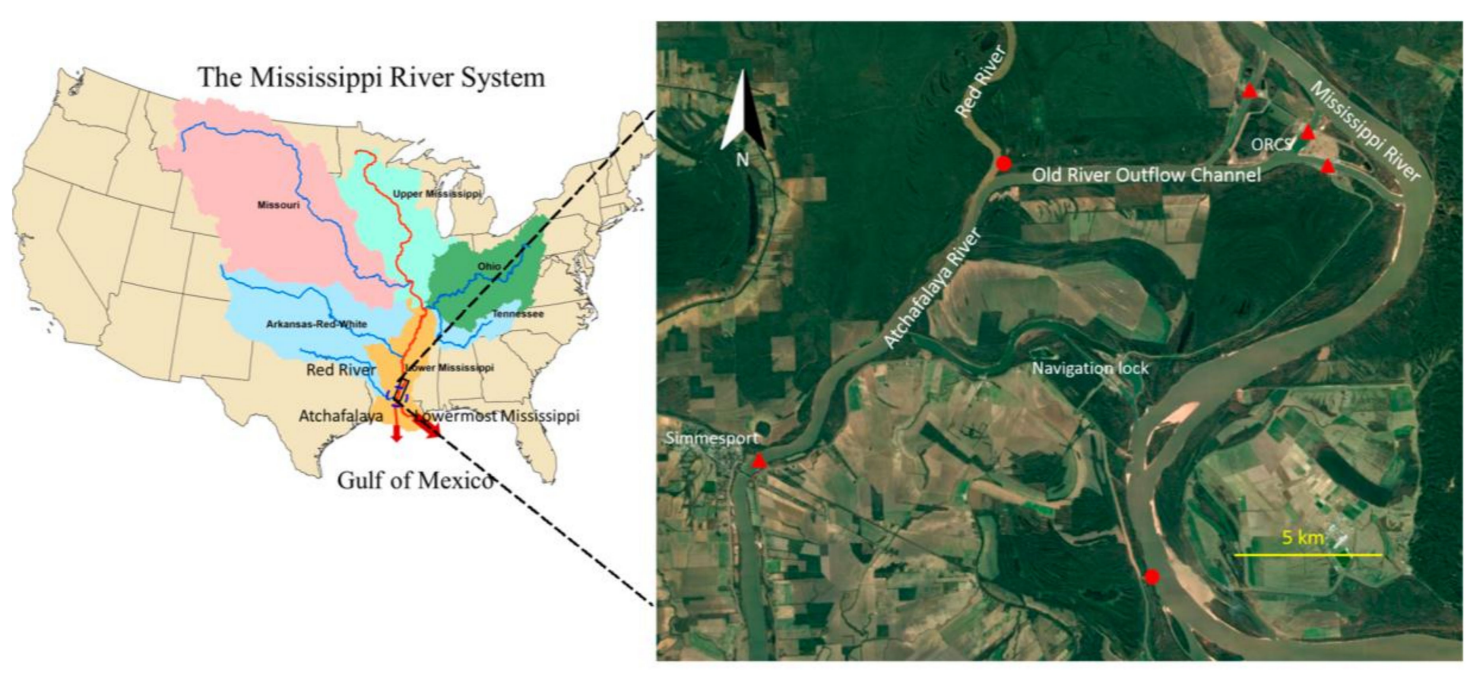

Figure 1. (Left) The Mississippi River drainage basin with two outlets: the Lowermost Mississippi River and the Atchafalaya River, which discharge a combined flow of approximately $680 \mathrm{~km}^{3}$ annually into the Gulf of Mexico; (Right) the Old River Control Structure (ORCS), where the Mississippi River's water is diverted to join the entire flow of the Red River, forming North America's largest swamp river-the Atchafalaya. The Atchafalaya River contributes a combined annual flow of approximately $200 \mathrm{~km}^{3}$ to the Gulf of Mexico. In this study, we collected water samples at two locations: on the Red River and on the Mississippi River at Angola Landing (red dots). River discharge records at Simmesport and Old River Outflow Channel (red triangles) were obtained from U.S. Geological Survey and U.S. Army Corps of Engineers, respectively.

\subsection{Water Sampling and Field Measurements}

To determine the Red River's contribution of dissolved carbon to the Atchafalaya, we collected monthly water samples on the Red River, about $400 \mathrm{~m}$ above the confluence of the Red River and Old River Outflow Channel, and on the Mississippi at Angola Landing, Louisiana (Figure 1), which is about $15 \mathrm{~km}$ downstream of the ORCS. It is assumed that the water chemistry at Angola Landing represent well that of diverted Mississippi River's water that is flowing through the Old River Outflow Channel. Sampling trips were conducted over a wide range of flow conditions (Figure 2), with four 
sampling trips taking place during low flow conditions, and nine trips taking place during high flow conditions (Figure 2) based on the long term average reported by Xu [26]. Several of these trips took place during periods where the Red River contributed a higher percentage of flow to the Atchafalaya River than did the Mississippi River, offering great sample diversity.

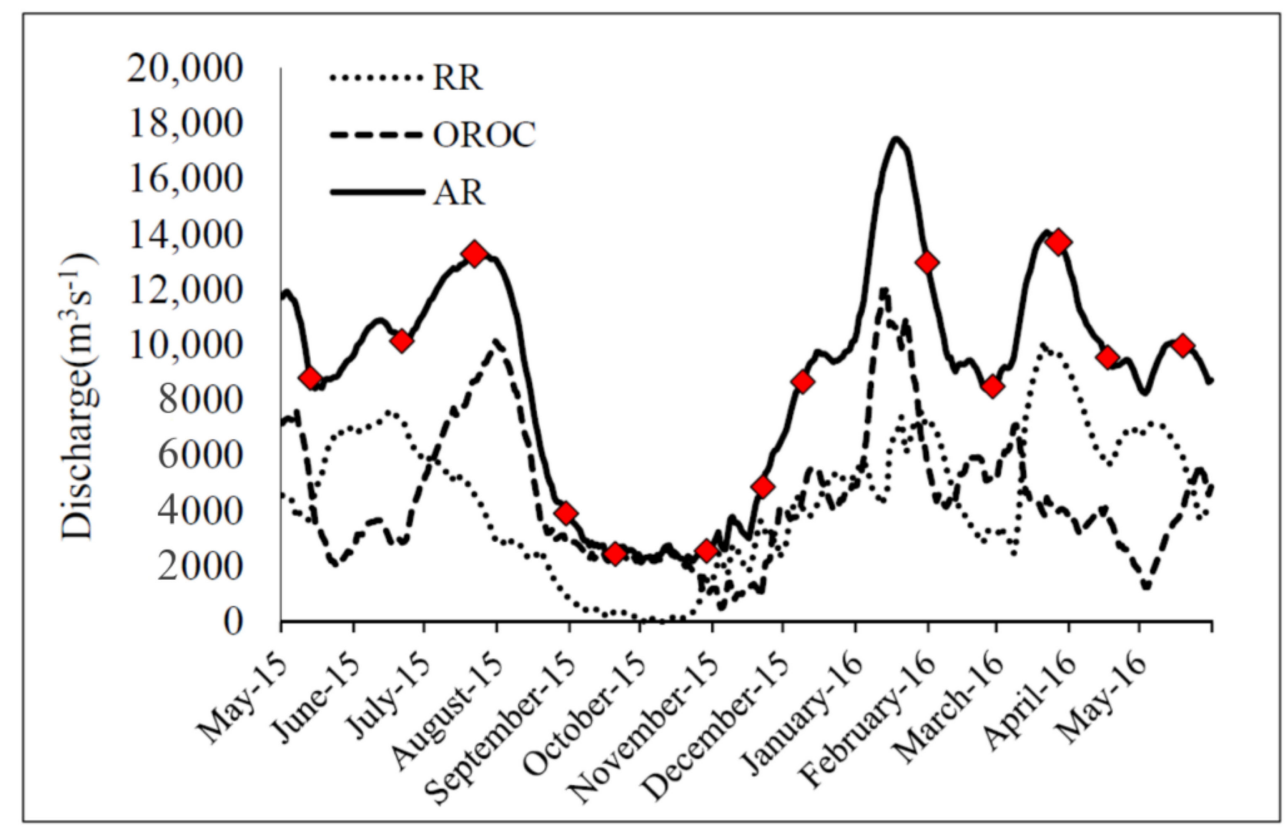

Figure 2. Daily inflows from the Mississippi River's Old River Outflow Channel (OROC) and the Red River (RR) into the Atchafalaya River (AR) during May 2015-31 May 2016. The inflows of the Red River were calculated as the difference between the AR's discharge at Simmesport (obtained from the United States Geological Survey) and the OROC's discharge (obtained from the United States Army Corp of Engineers). Diamonds depict water quality sampling and field measurement dates.

During each monthly sampling event, surface water samples were collected from boat launches at each site from the depth of $30-50 \mathrm{~cm}$ below water surface using an extendable sampler. Although it has been demonstrated that chemical constituents in fast-flowing waters of the AR are uniformly mixed [27], three samples were collected for each constituent to be analyzed, and were mixed to ensure a representative composite sample. Samples for DOC analysis were stored in 250-mL High Density Polyethylene (HDPE) bottles. Samples for DIC analysis were septum-capped in $20 \mathrm{~mL}$ glass vials and were immediately placed on ice, along with the DOC samples. All of the bottles for DIC stable isotope analyses were filled without headspace, and were closed with butyl rubber/PTFE septa. All of the bottles were thoroughly acid-cleaned and rinsed using river water before use. Duplicate samples were collected at one site per trip for quality control purposes. All of the water samples were stored in a cooler with wet ice during transportation. DIC samples were refrigerated until chemical analysis, while DOC samples were filtered using $0.45 \mu \mathrm{m}$ nylon syringe filters (Environmental Express, Charleston, SC, USA) and were frozen immediately upon return from sampling. In addition to the river water sampling during monthly field trips, ambient water parameters, including dissolved oxygen (DO), $\mathrm{pH}$, temperature, and specific conductance were recorded using a YSI 556 multi-probe meter (YSI Inc., Yellow Springs, OH, USA) at each location. Turbidity was measured with a 2100P Turbidimeter (Hatch Company, Loveland, CO, USA).

\subsection{Sample Analysis}

Upon returning to the lab, the samples to be analyzed for DOC and DIC were shipped on ice to University of California Davis Stable Isotope Facility (http:/ / stableisotopefacility.ucdavis.edu/). 
UC Davis provides $\delta^{13} \mathrm{C}$ isotope analysis of DIC by trace gas using a GasBench II system interfaced to a Delta V Plus IRMS (Thermo Scientific, Bremen, Germany), and $\delta^{13} \mathrm{C}$ isotope analysis of DOC using an O.I. Analytical Model TOC Analyzer (OI Analyticl, College Station, TX, USA) interfaced to an isotope ratio mass spectrometer (Sercon Ltd., Cheshire, UK). For further details on laboratory methods, refer to http:/ / stableisotopefacility.ucdavis.edu/.

Stable isotope values are expressed as deviations per mil (\%) from Vienna Pee Dee Belemnite (VPDB), which is a standard reference material based on the ratio of ${ }^{13} \mathrm{C} /{ }^{12} \mathrm{C}$ found in a highly ${ }^{13} \mathrm{C}$-rich belemnite fossil according to the formula:

$$
\delta^{13} \mathrm{C} \% 0=\left(\frac{R_{\text {sample }}}{R_{\text {standard }}}-1\right) \times 1000
$$

where $R$ is the ratio of the numbers $(n)$ of the heavy and light isotope of an carbon $\left({ }^{13} \mathrm{C} /{ }^{12} \mathrm{C}\right)$ in the sample and the reference [28].

\subsection{Carbon Mass Transport Calculation}

To estimate dissolved carbon loading with monthly sampling data, rating curves were developed with daily discharge records $(Q)$ and DIC and DOC measurements for the Red River and the Mississippi River's water from the Old River Outflow Channel. Discharge records of the Atchafalaya at Simmesport were gathered from the United States Geological Survey (USGS), and discharge records of the Old River Outflow Channel were collected from the United States Army Corps of Engineers (USACE). The discharge of the Red River was computed as the difference between the AR's and OROC's discharges.

A basic power law model for loading $(L), L=a Q^{b}$, was used, which can be log-transformed to a linear equation:

$$
\ln \left(L_{i}(t)\right)=A+b \ln \left(Q_{\text {day }}(t)\right)+\varepsilon(t)
$$

where $L_{i}(t)$ is the daily mass load of dissolved carbon constituents in metric tonnes, $i$ is the type of element for a certain site, $Q_{\text {day }}(t)$ is the daily flow volume in cubic meters, $A$ (i.e., $\ln a$ ) and $b$ are the model parameters, and $\varepsilon$ is an error term that is assumed to be normally distributed. $A$ and $b$ were determined using the SAS 9.4 software package (SAS Institute) and tested for Normality. The parameter fitting statistics were summarized in Table 1 and Figure 3.

Table 1. Statistics of parameterization $\left(A\right.$ and $b$ ) for Equation (2), regression coefficient $\left(R^{2}\right)$, root mean square error (RMSE), and standard error at a 95\% confidence interval. The equation was used to estimate daily loads of dissolved inorganic carbon (DIC) and dissolved organic carbon (DOC) from the Mississippi River through the Old River Outflow Channel (OROC) and the Red River (RR).

\begin{tabular}{ccccccc}
\hline Site & Load & $\boldsymbol{A}$ & $\boldsymbol{b}$ & $\boldsymbol{R}^{\mathbf{2}}$ & RMSE & $\boldsymbol{\varepsilon}$ \\
\hline \multirow{2}{*}{ OROC } & DIC & -8.799 & 0.903 & 0.851 & 0.243 & \pm 0.243 \\
& DOC & -17.413 & 1.275 & 0.895 & 0.276 & \pm 0.276 \\
\hline \multirow{2}{*}{ RR } & DIC & -4.957 & 0.667 & 0.928 & 0.193 & \pm 0.192 \\
& DOC & -15.459 & 1.204 & 0.955 & 0.268 & \pm 0.268 \\
\hline
\end{tabular}

\subsection{Estimation of Riverine $\mathrm{CCO}_{2}$}

The partial pressure of carbon dioxide in water was calculated according to the method shown by Cai and Wang [29], which uses DIC concentration and measured $\mathrm{pH}$ data in the equation:

$$
p \mathrm{CO}_{2}=\frac{\left[\mathrm{CO}_{2}\right]}{K_{H}}=\frac{C_{T}\{H\}^{2}}{\left(\{H\}^{2}+\{H\} K_{1}+K_{1} K_{2}\right) K_{H}}
$$


where $C_{T}$ is the measured DIC value in $\mathrm{mM},\{H\}=10-\mathrm{pH}, K_{H}$ is the solubility constant [30], and $K_{1}$ and $K_{2}$ are the dissociation constants of carbonic acid. Since sampled waters possessed salinity measurements of less than 0.2, the $K_{1}$ and $K_{2}$ of Harned and Davis [31] and Harned and Scholes [32] were used, respectively, for salinities near $0 . K_{H}, K_{1}$, and $K_{2}$ are all adjusted for absolute water temperature. The parameter settings are summarized in Table S1 in Supplementary Materials.

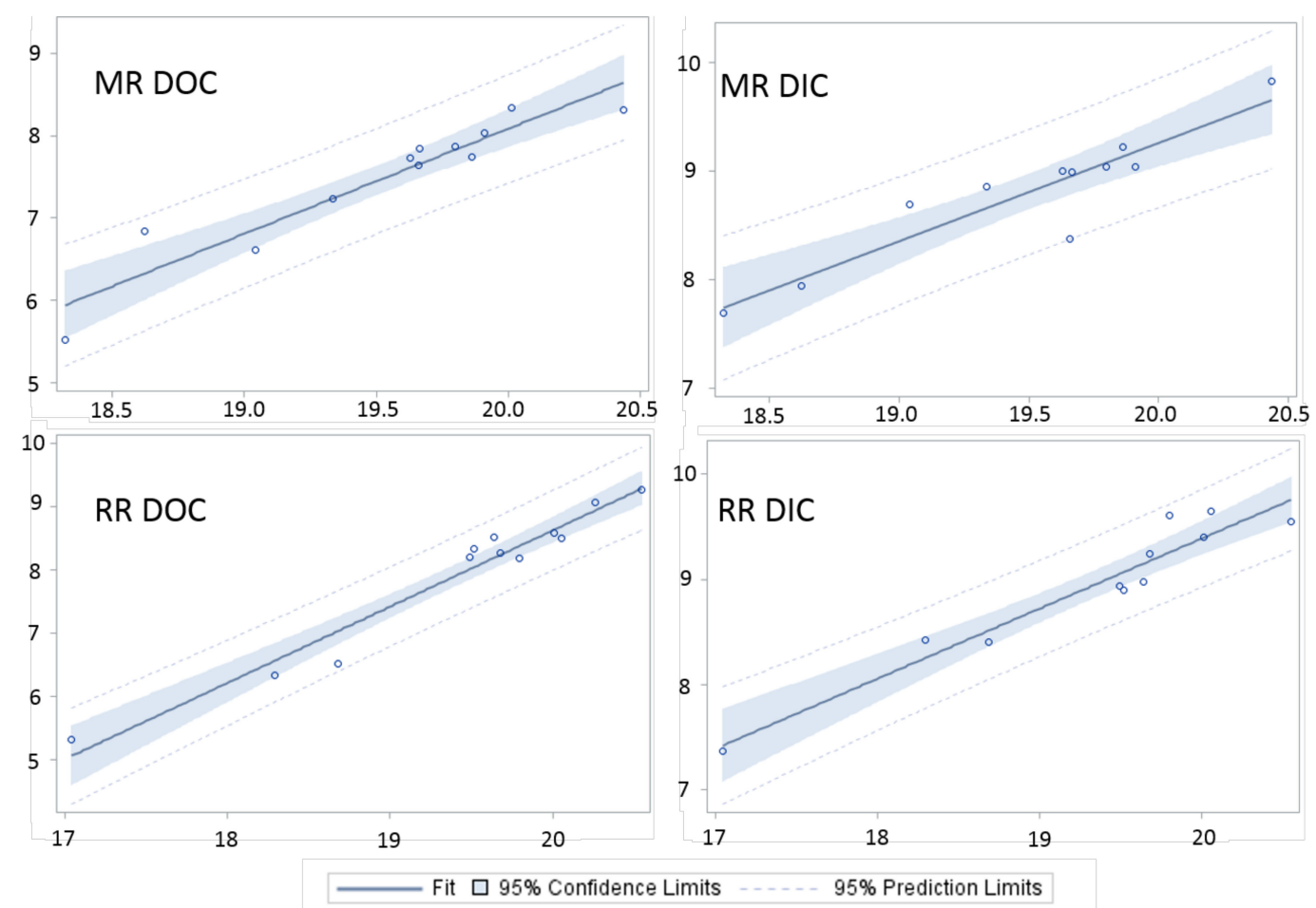

Figure 3. Statistical performance of the rating curves (Table 3) for estimating DOC and DIC daily mass loads of the Mississippi River (above) and Red River (below). The $X$ axis are $\ln \left(Q_{\text {day }}\right)$ and the $Y$ axis are $\ln \left(L_{i}\right)$ in Equation (2).

\subsection{Statistical Analysis}

As mentioned above, regression analysis was used to develop rating curves for mass loading of DOC and DIC. The Shapiro-Wilk test was used to test all of the water parameters (including DOC, DIC, $p \mathrm{CO}_{2}$, and $\delta^{13} \mathrm{C}$ ) for normality, and the results showed large $p$-values (mostly $>0.6$, v.s. $p>0.05$, which is required for rejecting Null hypothesis), indicating a normal distribution of the data. A paired $t$-test was used to determine if a significant difference existed in the parameters between the Red River's and Mississippi River's waters. All of the statistical analyses were performed with the SAS Statistical Software package (SAS Institute Inc., Cary, NC, USA).

\section{Results}

\subsection{River Flow and Ambient Conditions}

During the study period from May 2015 through May 2016, the flow of the Red River entering the Atchafalaya River averaged 4429 (standard deviation: \pm 2550$) \mathrm{m}^{3} \cdot \mathrm{s}^{-1}$, ranging from negligible flow in the fall to $10,137 \mathrm{~m}^{3} \cdot \mathrm{s}^{-1}$ in March. Mean daily discharge from the Old River outflow channel into the Atchafalaya was $4473( \pm 2477) \mathrm{m}^{3} \cdot \mathrm{s}^{-1}$; with a minimum flow rate of $481 \mathrm{~m}^{3} \cdot \mathrm{s}^{-1}$ in November and a maximum discharge of $12,063 \mathrm{~m}^{3} \cdot \mathrm{s}^{-1}$ in January. The combined flow from the two rivers averaged $8901( \pm 3885) \mathrm{m}^{3} \cdot \mathrm{s}^{-1}$ at Simmesport, falling as low as $2166 \mathrm{~m}^{3} \cdot \mathrm{s}^{-1}$ in late October and reaching a maximum rate of $17,443 \mathrm{~m}^{3} \cdot \mathrm{s}^{-1}$ in mid-January. On average, the Red River contributed $\sim 46.5 \%$ of 
the Atchafalaya River's flow, with a maximum contribution of $\sim 85 \%$ in April 2016. The waters of the Red River made up a greater portion of the AR's daily flow at Simmesport than did the MR on $47.6 \%$ of days included in the sampling period ( $n=397$ days). Mean daily discharge rates varied somewhat dramatically by season. Lowest average daily flows at Simmesport occurred throughout fall $\left(3126 \mathrm{~m}^{3} \cdot \mathrm{s}^{-1}\right)$, followed by summer $\left(10,401 \mathrm{~m}^{3} \cdot \mathrm{s}^{-1}\right)$, and spring $\left(10,619 \mathrm{~m}^{3} \cdot \mathrm{s}^{-1}\right)$, with highest average daily flow occurring in winter $\left(11,234 \mathrm{~m}^{3} \cdot \mathrm{s}^{-1}\right)$.

It is important to note that discharge at Simmesport during this 13-month period $\left(8901 \mathrm{~m}^{3} \cdot \mathrm{s}^{-1}\right)$ was much higher than the long-term (1978-2004) annual average $\left(6547 \mathrm{~m}^{3} \cdot \mathrm{s}^{-1}\right)$, as reported by Xu [26], and also exceeded values reported by USGS for Water Years 2010-2015, which averaged $6187 \mathrm{~m}^{3} \cdot \mathrm{s}^{-1}$ (with yearly averages ranging from $4967 \mathrm{~m}^{3} \cdot \mathrm{s}^{-1}$ to $7229 \mathrm{~m}^{3} \cdot \mathrm{s}^{-1}$ ). Hence, the wet year may have discharged higher quantities of carbon and other elements.

Waters of the Red River showed significantly higher temperature $(p<0.0001)$, but no significant differences in dissolved oxygen saturation, turbidity, or $\mathrm{pH}$ (Table 2).

Table 2. Average ambient conditions ( \pm standard deviation) of waters of the Mississippi River at Angola and the Red River above the confluence with the Mississippi River. The different letters within a column indicate significant difference at $\alpha<0.05$.

\begin{tabular}{ccccc}
\hline Site & Temperature $\left({ }^{\circ} \mathbf{C}\right)$ & DO $\mathbf{~ \% ) ~}$ & pH & Turbidity \\
\hline MR & $18.0 \pm 8.0$ & $84.6 \pm 24.1$ & $7.3 \pm 0.9$ & $80.2 \pm 45.9$ \\
RR & $21.4 \pm 7.1$ & $75.4 \pm 24.6$ & $7.6 \pm 0.6$ & $113.7 \pm 75.6$ \\
\hline
\end{tabular}

\subsection{DOC and DIC Concentrations and Ratios}

Dissolved organic carbon and dissolved inorganic carbon concentrations showed a clear distinction between the waters of the RR and MR. DOC concentrations in the Red River (average: $871 \mu \mathrm{mol} \cdot C \cdot \mathrm{L}^{-1}$, Table 3) were significantly higher than in the samples collected from the MR (509 $\left.\mu \mathrm{mol} \cdot \mathrm{C} \cdot \mathrm{L}^{-1}\right)$, typically nearly twice as high (177\% higher on average), while the RR's DIC concentrations (average: $1034 \mu \mathrm{mol} \cdot C \cdot \mathrm{L}^{-1}$ ) were typically half of those $(49.2 \%$ lower) found in the MR at Angola (average: $1939 \mu \mathrm{mol} \cdot \mathrm{C} \cdot \mathrm{L}^{-1}$ ). The variable mixing of the waters of these two rivers to form the Atchafalaya therefore results in complex trends in dissolved carbon at Simmesport, depending on the relative contribution of each river at any given point on the hydrograph.

Table 3. DOC and DIC concentrations $\left(\mu \mathrm{mol} \cdot \mathrm{L}^{-1}\right)$ in the RR and Mississippi River (MR) during each sampling event. Different letters in averages indicate a statistically significant difference $(\alpha=0.05)$. The river flows were low from August to November in the study period (see Figure 2).

\begin{tabular}{ccccc}
\hline & \multicolumn{2}{c}{ DOC } & \multicolumn{2}{c}{ DIC } \\
\cline { 2 - 5 } & RR & MR & RR & MR \\
\hline 13 May 2015 & 1225 & 454 & 718 & 1993 \\
21 June 2015 & 692 & - & 1343 & - \\
22 July 2015 & 749 & 451 & 1148 & 2052 \\
30 August 2015 & 533 & 465 & 1582 & 2345 \\
20 September 2015 & 678 & 336 & 1927 & 2667 \\
29 October 2015 & 433 & 229 & 1051 & 2027 \\
22 November 2015 & 1169 & 640 & 750 & 1908 \\
9 December 2015 & 914 & 552 & 895 & 1766 \\
31 January 2016 & 1139 & 711 & - & - \\
28 February 2016 & 1034 & 583 & 804 & 1586 \\
27 March 2016 & 1044 & 502 & 511 & 1048 \\
17 April 2016 & 917 & 567 & 759 & 2019 \\
19 May 2016 & 801 & 610 & 928 & 1921 \\
Mean & $871^{\text {a }}$ & $509^{\text {b }}$ & $1035^{\mathrm{c}}$ & 1939 d \\
Std dev & \pm 249 & \pm 133 & \pm 407 & \pm 409 \\
\hline Notes: “a-d" means with the same letter are not significantly different.
\end{tabular}


During the period of low flow from August through November, DOC fell to somewhat lower concentrations relative to the rest of the sampling period, while DIC concentrations were relatively heightened. DIC was highest in the RR in August and September and were the lowest in March, and DIC in the MR showed the same trend. The RR's DOC concentration was measured at its lowest in October and highest in May 2015, and the MR's DOC concentration was also lowest in October, but highest in January.

The ratios of DIC:DOC in these two rivers also differed greatly (Figure 4). The MR's mean DIC:DOC was 4.4, and never fell below 2. The ratio of DIC to DOC in the MR was especially high (nearing 9) during September and October, when DOC in the MR dropped to the lowest observed concentrations (Table 3). The RR's DIC:DOC, however, was often below 1, and never exceeded 3. Seasonal variations in DIC:DOC in the RR were less extreme than those in the MR, but showed similar increase in fall months.

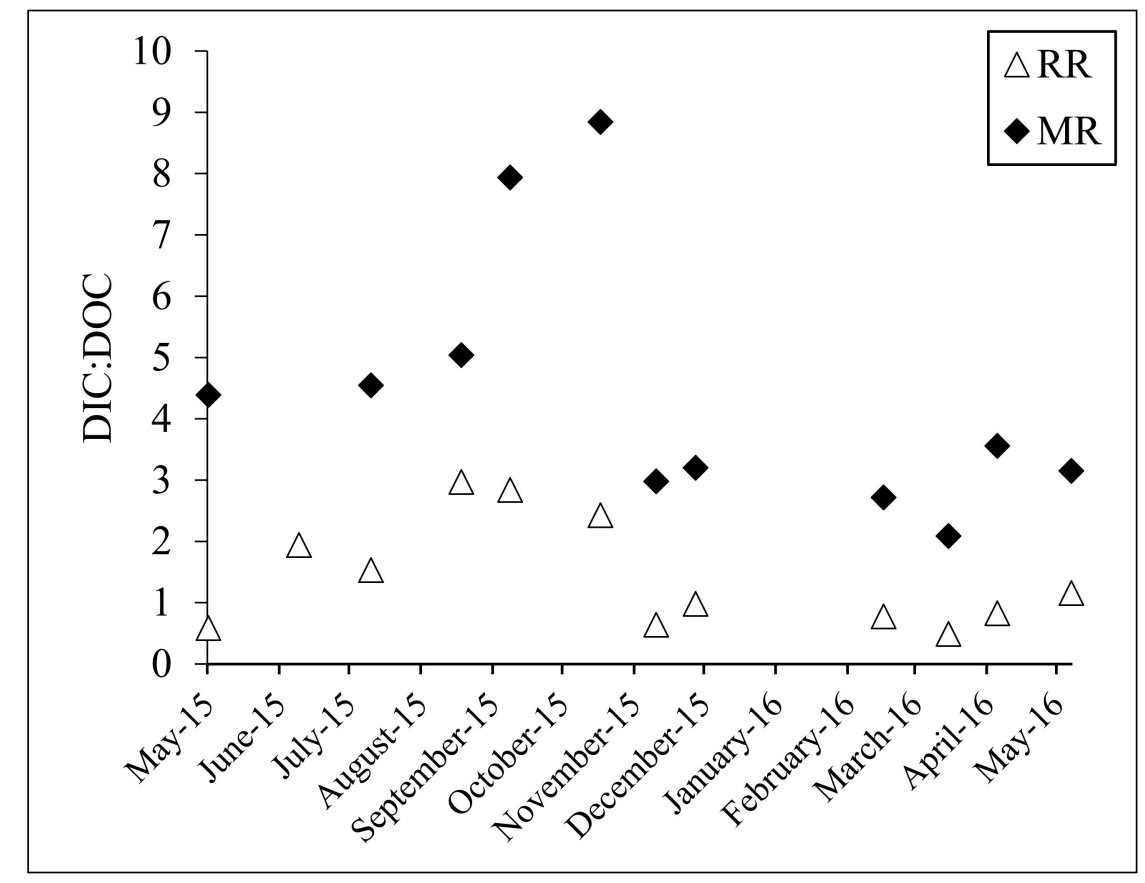

Figure 4. Ratio of DIC to DOC in the Atchafalaya River's two tributaries before their confluence on monthly sampling dates from May 2015 to May 2016.

\section{3. $p \mathrm{CO}_{2}$ Fluctuations}

Based on calculated $p \mathrm{CO}_{2}$, waters from both of the rivers were found to be consistently saturated with $\mathrm{CO}_{2}$ relative to atmospheric pressure (Figure 5), with the exception of December 2015, where $p \mathrm{CO}_{2}$ fell to $227 \mu \mathrm{atm}$. The MR was significantly $(p=0.012)$ more saturated than the RR in terms of $p \mathrm{CO}_{2}$. Carbon dioxide pressure in the MR ranged from $730 \mu \mathrm{atm}$ (March 2016) to $3595 \mu \mathrm{atm}$ (May 2015), and from $227 \mu \mathrm{atm}$ (December 2015) to $3328 \mu \mathrm{atm}$ (May 2015) in the RR, and both rivers showed lower $p \mathrm{CO}_{2}$ in the winter and higher $p \mathrm{CO}_{2}$ in the summer. $p \mathrm{CO}_{2}$ could not be calculated for either site in January 2016 due to a lack of DIC measurements, or in March 2016 due to $\mathrm{pH}$ probe malfunction. 


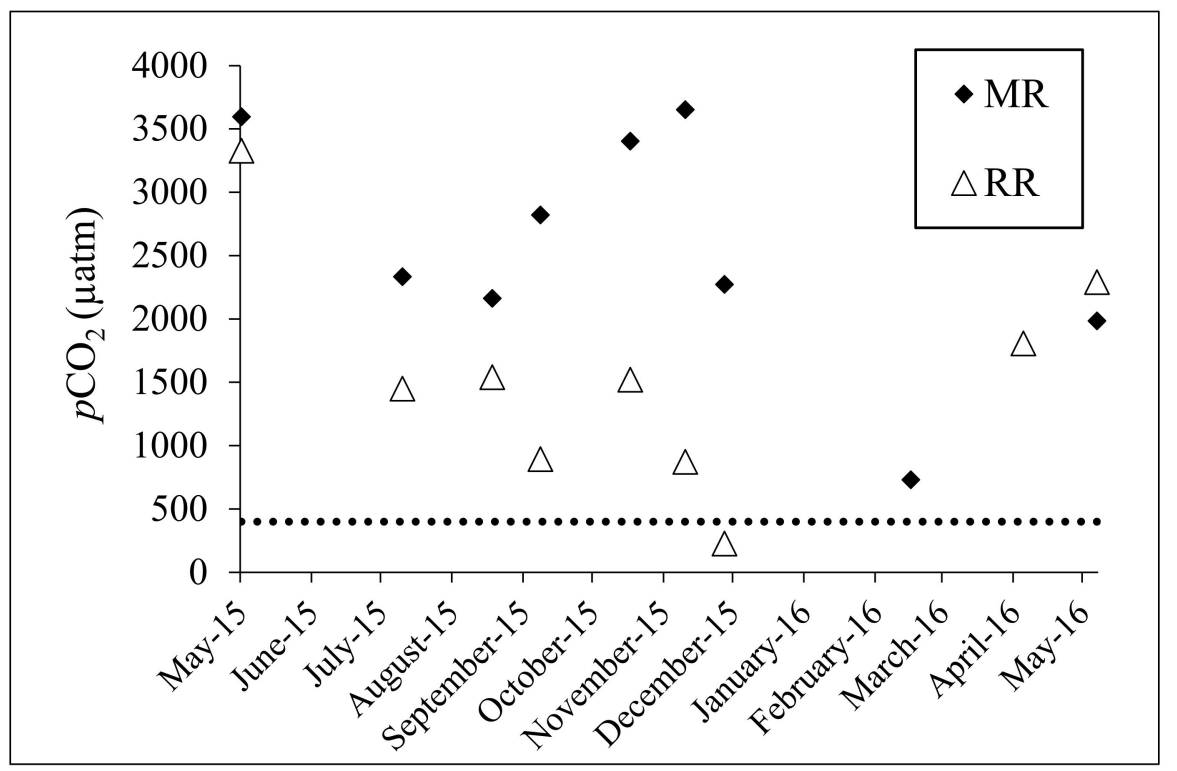

Figure 5. Calculated $p \mathrm{CO}_{2}$ in the Atchafalaya River's two tributaries before their confluence from sampling dates from May 2015 to May 2016 (no calculation is available for sampling events on 31 January 2016 or 27 March 2016; see Table S1 in Supplementary Materials). The dashed line represents atmospheric $\mathrm{CO}_{2}$ conditions.

\subsection{DOC and DIC Mass Transport}

For the sampling period, the discharge rating curve model estimated that the Red River contributed 1.41 teragrams ( $\mathrm{Tg}$ ) of the $4.76 \mathrm{Tg}$ DIC calculated mass load passing through the Atchafalaya River at Simmesport (or, $29.7 \%$ of total DIC), and $1.74 \mathrm{Tg}$ of the $2.75 \mathrm{Tg}$ DOC calculated mass load passing through Simmesport (or, 63.2\% of total DOC) (mass load at Simmesport is assumed to equal the combined loads calculated for the RR and MR). The relative contributions of the Red River and the Mississippi River to the AR's dissolved carbon budget varied seasonally according largely to discharge. On average, the Red River contributed $30.8 \%$ of the daily total DIC mass load to the Atchafalaya River, ranging from negligible contributions when discharge was minimal, to a maximum of upwards of 65\% in November 2015 and May 2016 when RR's waters made up more than $80 \%$ of the AR's flow (Figure 6).

The Red River's total contribution to DOC mass loading in the AR was disproportionately high, especially in comparison to its contribution to DIC flux (Figure 6). On average, the Red River contributed $57.5 \%$ of the daily total DOC mass load to the AR, ranging from negligible contributions when the discharge was minimal, to maximums of greater than 90\% in November 2015 and May 2016. The RR frequently contributed a greater percentage of the AR's DOC mass load than did the MR (observed on $62 \%$ of $n=397$ days). However, it rarely contributed a greater portion of the Atchafalaya's total DIC (observed on $8 \%$ of $n=397$ days). 

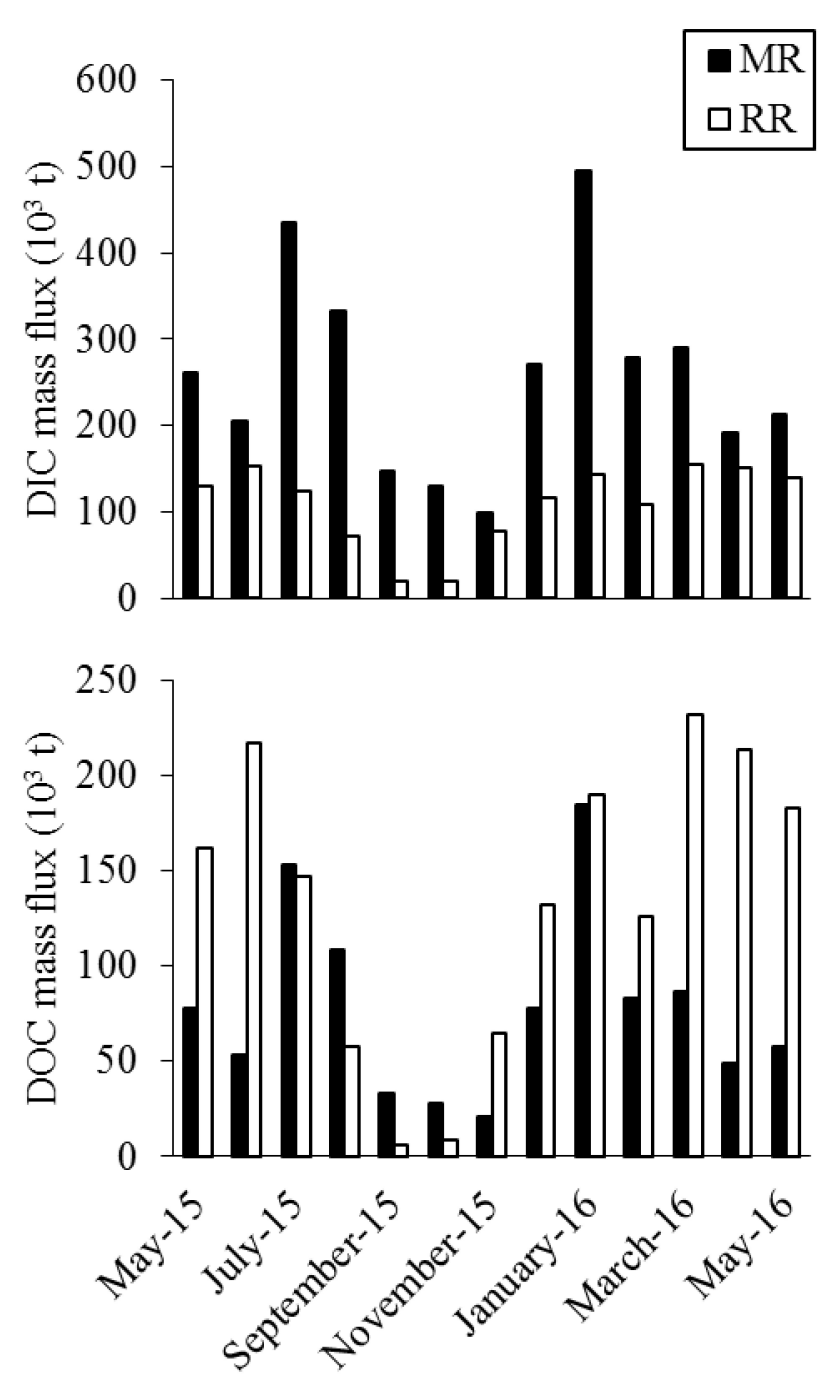

Figure 6. Monthly mass fluxes of DIC and DOC of the Mississippi River at the ORCS and Red River before the confluence with the Old River. The river flows were low from August to November in the study period (see Figure 2).

\subsection{Isotopic Signature of Dissolved Carbon}

$\delta^{13} C_{\text {DIC }}$ values varied significantly $(p<0.0001)$ between the RR and MR, which had average values of $-15.3 \pm 1.9$ and $-12.0 \pm 0.9(\% \mathrm{VPDB})$, respectively (Figure 7$)$. Both tributaries to the Atchafalaya showed enrichment in ${ }^{13} \mathrm{C}_{\text {DIC }}$ throughout summer before becoming more depleted throughout late fall and winter. $\delta^{13} \mathrm{C}_{\mathrm{DIC}}$ values in the RR showed a strong positive relationship with DIC concentrations $\left(R^{2}=0.71, p=0.006\right)$, but $\delta^{13} C_{\text {DIC }}$ values in the MR showed no significant relationship with the DIC concentrations $\left(R^{2}=0.21, p=0.15\right)$. 


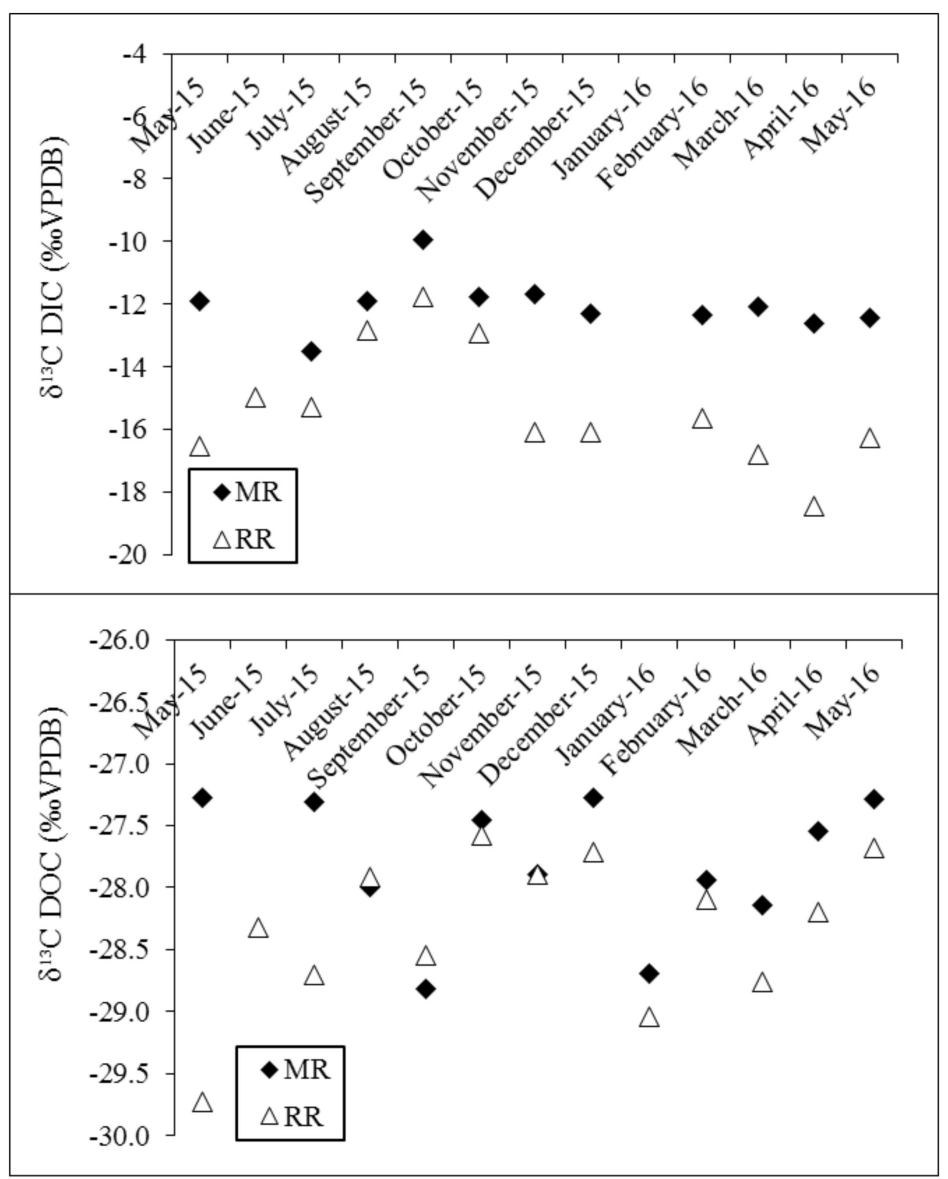

Figure 7. $\delta^{13} \mathrm{C}_{\mathrm{DIC}}\left(\%\right.$ Vienna Pee Dee Belemnite (VPDB)) and $\delta^{13} \mathrm{C}_{\mathrm{DOC}}\left(\%_{0}\right.$ VPDB) signatures in the AR's two major tributaries, the RR and MR, before their confluence.

$\delta^{13} \mathrm{C}_{\mathrm{DOC}}$ values were also found to differ significantly $(p=0.03)$ between the AR's two tributaries. Average values in the RR and MR were $-28.3 \pm 0.6$ and $-27.8 \pm 0.5$ (\% VPDB), respectively (Figure 6). $\mathrm{DOC}$ in the RR was generally slightly more depleted in ${ }^{13} \mathrm{C}$ than the MR. There was no clear seasonality of $\delta^{13} \mathrm{C}_{\mathrm{DOC}}$ values; depletion and enrichment was somewhat chaotic throughout the study, but both rivers showed a similar overall trend. The majority of values remained well within the range of -27 to $-29(\% \mathrm{VPDB})$ for all of the sampling locations. Isotopic composition of DOC did not exhibit significant correlation with DOC concentration values at either site (RR: $R^{2}=0.28, p=0.06$; MR: $R^{2}=0.01, p=0.75$ ) and was not clearly related to any seasonal trends in DOC concentrations.

\section{Discussion}

\subsection{Red River Influence on AR Carbon Concentrations and Mass Loads}

The Red River significantly impacted dissolved carbon loading in the Atchafalaya River. The Red River's average contribution to DOC mass loading in the Atchafalaya River was much greater than its contribution to DIC mass loading. The RR more often contributed greater amounts of DOC than did the MR, but its estimated contribution to DIC mass loading was less than that of the MR during $92 \%$ of the study period. Overall, the Red River contributed $29.7 \%$ of the total calculated mass load of DIC passing through the Atchafalaya River at Simmesport, but a much greater total of $63.2 \%$ of DOC calculated mass load passing through Simmesport.

A 2012 study characterized AR and MR DOC using chromophoric dissolved organic matter, total dissolved lignin phenols, amino acids, and neutral sugars during five cruises in the NGOM [18]. The study suggested that the RR may account for only $~ 13 \%$ of the elevated DOC concentrations in 
the AR when compared to the MR, attributing the remainder to inputs from the AR's floodplains. This present study suggests, however, that the RR may have a much greater contribution to DOC mass loading in the AR than has been previously indicated. The RR did not contribute directly to the enhancement of DIC loads, but rather had a dilution effect on the MR's high DIC concentrations. However, by providing large loads of DOC, which may be rapidly mineralized to DIC, the RR may still have an indirect impact on end-member DIC export from the AR.

\subsection{Sources and Processes Determining Dissolved Inorganic Carbon in the AR}

Significant differences in carbon isotope values between these two tributaries indicate different sources, and potentially different quality, of carbon constituents. Based on the relative abundance of $\mathrm{C}_{3}$ and $\mathrm{C}_{4}$ plants in the Mississippi River Basin ( 72.7\% and $\sim 27.3 \%$, respectively), Dubois et al. [25] estimated that soil respired $\mathrm{CO}_{2}$ in the MR basin should have an average isotopic signature of $\sim-23.5 \%$. According to carbonate dissolution stoichiometry, the final $\delta^{13} \mathrm{C}_{\mathrm{DIC}}$ value can be estimated as a 1:1 mixture of dissolved carbonates, which typically have a value near $0 \%$ [20], and dissolved soil $\mathrm{CO}_{2}$. Therefore, we would expect the average $\delta^{13} \mathrm{C}_{\mathrm{DIC}}$ value in the lower Mississippi River to be half of the Dubois et al. reported soil $\mathrm{CO}_{2}$, i.e., $\sim-11.75 \%$, assuming an equal contribution of soil emission and carbonate dissolution. The average value found in this study, $-12.0 \pm 0.9 \%$, agrees well with this expected value. This value is subject to enrichment by diffusion processes $(+4.4 \%$; [33]), as well as by gas transfer $(+0.85 \%$; [34]).

Using the methodology of Dubois et al. [25], we can attempt to estimate an average expected isotopic value for the $\mathrm{CO}_{2}$ Red River basin's soil, which heavily influences aquatic $\delta^{13} \mathrm{C}_{\text {DIC }}$. Nearly half of the vegetation in the RR basin is estimated to be made up by grasses [35], and between $60 \%$ and $70 \%$ of those grass species are estimated to use the $C_{4}$ photosynthetic pathway [36]. Assuming $65 \%$ of grasses in the Red River Basin use a $C_{4}$ pathway, the relative abundance of $C_{3}$ and $C_{4}$ plants in the basin would be $67.5 \%$ and $32.5 \%$, respectively. Based on this, it can be roughly estimated that the Red River Basin soils have an average soil $\mathrm{CO}_{2}$ isotopic value of about $-22.8 \%$, and an average $\delta^{13} \mathrm{C}_{\mathrm{DIC}}$ signature of about $-11.4 \%$ in the river water. This estimated value departs greatly from the average value found in this study, $-15.3 \pm 1.9 \%$, which may indicate interesting sources and processing of carbon in this system.

Due to the nature of this study, it is impossible to constrain with exact certainty which processes are responsible for the very negative signature of DIC in the RR. However, existing literature allows us to point to several probable causes. The differences in isotope values may be partially attributed to climate conditions in the RR basin. The western grassland-dominated portion of the basin experiences arid, low precipitation conditions, occasionally lacking flow altogether, while the temperate, forested eastern region of the basin experiences high rainfall ( $1500 \mathrm{~mm}$ annually). DOC is known to be exported at higher rates in accordance with rainfall and higher discharge [18,37-40]. The majority of soil carbon in the RR then, likely comes from the $C_{3}$ dominant temperate eastern region, which would partially explain lower values than what would be observed if precipitation was equal in the $\mathrm{C}_{4}$ dominated western region.

Voss et al. [41] showed that in-stream processes such as respiration and photosynthesis were primary drivers determining $\delta^{13} \mathrm{C}_{\mathrm{DIC}}$ values, and that in-stream signatures were distinct from their source signatures. The discrepancy between the expected and reported $\delta^{13} \mathrm{C}_{\mathrm{DIC}}$ values for the RR could be indicative of the importance of in-stream respiration in its warm waters, which causes more negative values through the removal of ${ }^{13} \mathrm{C}$ from the aquatic carbon pool [25]. The significantly lower $\delta^{13} C_{\mathrm{DIC}}$ values in the RR as compared to the MR may then also be indicators of a more active biotic community and greater overall rates of respiration. This study indicates both inputs of carbon from the RR's temperate forested landscape and active in-stream processes as contributing to the highly negative $\delta^{13} \mathrm{C}_{\mathrm{DIC}}$ values that were found during this study.

The more negative isotopic values of DIC in the RR are typically observed in regions that are less degraded by anthropogenic alteration, whereas ${ }^{12} \mathrm{C}$ depleted values, such as those found in the 
MR, are characteristic of human-dominated watersheds with large agricultural and urban centers, where heightened DIC concentrations lead to increased weathering and atmospheric degassing [42]. These values might illustrate important differences in the quality of carbon sources in these two rivers.

The highest $\delta^{13} C_{\text {DIC }}$ values occurred in both rivers in September, which corresponded with the highest concentrations of DIC in both rivers. $\mathrm{CO}_{2}$ degassing can occur more rapidly when there is a greater difference between partial pressure of carbon dioxide in the air and in the water, as would be indicated by heightened DIC concentrations [43]. Calculated $p \mathrm{CO}_{2}$ values based on reported DIC concentrations demonstrated that both tributaries to the AR were supersaturated with carbon dioxide in respect to the theoretical atmospheric value of $390 \mathrm{ppm}$ [44]. Atmospheric degassing causes the preferential loss of the ${ }^{12} \mathrm{C}$ isotope, resulting in a carbon pool that is enriched in ${ }^{13} \mathrm{C}$, which may provide an explanation for the more positive $\delta^{13} \mathrm{C}_{\text {DIC }}$ values occurring in the MR (i.e., [45]). However, seasonally, highest $p \mathrm{CO}_{2}$ values (and thus highest rates of evasion) occurred in the winter and did not correspond with the increased values of $\delta^{13} \mathrm{C}_{\mathrm{DIC}}$ in late summer and early fall months (Figures 4 and 6). Though degassing likely impacted DIC isotopic composition in both rivers, it is clear that it was not a controlling factor. Since discharge was lowest when the $\delta^{13} C_{\text {DIC }}$ values were highest (Figures 2 and 6), riverine DIC may have been more strongly influenced by local soil weathering and groundwater, which are both relatively enriched in ${ }^{13} \mathrm{C}[14,46,47]$ during these low flow, high concentration conditions. Since the RR contributed $\sim 46.5 \%$ of the AR's flow but only $\sim 30.8 \%$ of daily DIC mass load on average, its impacts on isotopic values of the AR's waters are proportionally less than that of the MR. The $\delta^{13} \mathrm{C}_{\text {DIC }}$ signature of carbon exported to the NGOM can thus be expected to more closely resemble the less negative DIC isotopic values that are found in the MR.

\subsection{Differences in Dissolved Organic Carbon Sources Entering the AR}

The AR's $\delta^{13} C_{\mathrm{DOC}}$ values, on the other hand, can be expected to be somewhat dominated by the significantly more negative signatures that are representative of the $R R$, since it contributed an estimated $\sim 57.5 \%$ of the AR's daily DOC mass load on average. The MR and RR's relative influences on organic carbon isotopic signatures in the AR should then be closer to a 1:1 mixing ratio. $\delta^{13} C_{\mathrm{DOC}}$ values retain information about terrestrial sources [41], so although the flow of the MR dominates the AR, organic carbon in the AR can be expected to be highly reflective of the organic material that is found in the soils of the RR basin. In a recent study of isotope signatures in the upper MR, Voss et al., [41] revealed that $\delta^{13} \mathrm{C}_{\mathrm{DOC}}$ values became more negative with increased forest cover. This may further implicate the forested eastern region of the RR as the primary contributor of carbon in the RR. However, reliable interpretation of $\delta^{13} \mathrm{C}_{\mathrm{DOC}}$ signatures is complicated by the overlapping signatures of major DOC sources [48], thus making it difficult to constrain the age or bioavailability of carbon in these tributaries.

The preferential use of atmospheric ${ }^{12} \mathrm{C}$ for photosynthetic processes gives fresh plant material a more negative signature; more negative $\delta^{13} \mathrm{C}_{\mathrm{DOC}}$ signatures in the RR could then also indicate higher concentrations of plant material or algal signatures as a consequence of higher in-stream primary production [41,49]. Additional information on the quality of riverine organic matter can be obtained by determination of chlorophyll $a[50,51]$, which is derived from pigmented plant material and algal production. Higher chlorophyll $a$ content generally indicates younger and less degraded organic material, since chlorophyll $a$ is rapidly degraded in the presence of light and oxygen, thereby becoming more depleted in older material [52]. A 2010 study of the Red River basin found that the 25th percentiles of chl- $a$ concentrations measured throughout the basin from 1996-2006 dramatically exceeded USEPA recommended values, particularly in the basin's largest ecoregions [53]. Low ratios of DIC:DOC in the $\mathrm{RR}$, generally below 1 (Figure 4), may also indicate the conversion of aqueous $\mathrm{CO}_{2}$ to organic $\mathrm{C}$ by phytoplankton via in-stream primary production. The RR's heightened DOC concentrations depleted in ${ }^{12} \mathrm{C}$ found during this study, in conjunction with knowledge of high chl- $a$ content, may indicate that the RR plays a significant role in delivering large quantities of bioavailable organic material to the Atchafalaya River. 
While there was no relationship between $\delta^{13} C_{\mathrm{DOC}}$ and $\delta^{13} \mathrm{C}_{\mathrm{DIC}}$ values in the MR $\left(R^{2}=0.05\right.$, $p=0.50$ ), there was a relatively strong negative relationship between $\delta^{13} \mathrm{C}_{\mathrm{DOC}}$ and $\delta^{13} \mathrm{C}_{\mathrm{DIC}}$ values in the RR $\left(R^{2}=0.57, p<0.01\right)$. This suggests that the sources and the processing of DIC and DOC in the $\mathrm{RR}$ are closely interrelated. Coupling of DIC and DOC processing can occur when DIC is produced as a direct result of mineralization of DOC, or when DIC is taken up to produce organic material in stream [54]. DOC concentrations in the RR were relatively low during low flow conditions, while DIC concentrations were relatively higher, exhibiting the largest DIC:DOC ratios that were observed during this study period. This may be partially due to the increased residence time during low flow conditions where bio-mineralization processes can significantly impact concentrations [55]. It has been demonstrated that the active consumption of dissolved organic matter occurs at the highest rates when DOM is produced in-stream and is less altered, and that these processes were more likely to occur in low flow conditions [56]. The relationship between $\delta^{13} \mathrm{C}_{\mathrm{DOC}}$ and $\delta^{13} \mathrm{C}_{\mathrm{DIC}}$ in the RR (and lack of relationship in the MR), the RR's low DIC:DOC ratios, and isotopic indication of respiration and algal production, all may point to autochthonous production of DOC as a major contributor to the RR's high DOC loads. The seemingly active production and remineralization of carbon in the RR could have important impacts on nutrient cycling in the AR and subsequently in the NGOM. The impacts of the RR's large and potentially biologically active organic carbon loads on the formation of the annual hypoxic dead zone in the NGOM warrant further study.

\section{Conclusions}

This study provides insights into the role the Red River plays in tributary input of dissolved carbon to the Atchafalaya River, the North America's largest swamp river, filling in a knowledge gap that is important to understanding carbon dynamics in the Mississippi-Atchafalaya River System. While the Mississippi River delivered the vast majority of DIC to the AR, the Red River was found to contribute to over half of the total DOC entering the AR, which is greater than previously expected. We found significantly higher isotopic depletion in both dissolved organic carbon and dissolved inorganic carbon $\left(\delta^{13} \mathrm{C}_{\mathrm{DIC}}\right.$ and $\left.\delta^{13} \mathrm{C}_{\mathrm{DOC}}\right)$ in the Red River than those of the Mississippi River. This, in conjunction with significant differences in DIC and DOC concentrations and mass loads, demonstrates notable differences in the sources and quantity of carbon delivered to the AR by these two tributaries. The study strongly suggests disproportionately high mass contributions of DOC of potentially different quality to the AR via the RR, as well as an important dilution effect on the anthropogenically-enhanced DIC flux from the diverted portion of the MR. The contribution of the Red River thus represents a significant component of dissolved carbon dynamics in the Atchafalaya River, and should be taken into account when developing carbon budgets for the Northern Gulf of Mexico. The RR likely plays a critical role in determining end-member contributions of the AR to the coast, impacting estuarine and coastal processes, as well as $\mathrm{CO}_{2}$ flux to the atmosphere. Since this study was conducted during a relatively high-flow year, additional work must be done to determine whether the RR is the major contributor of DOC across all of the flow conditions.

Supplementary Materials: The following are available online at www.mdpi.com/2073-4441/9/11/871/s1, Table S1: Parameters and constants used in the calculation of $p \mathrm{CO}_{2}$ values.

Acknowledgments: This study was mainly supported through a grant from the United States National Fish and Wildlife Foundation (Project \#: 8004.12.036402). Also, a grant from the United States Department of Agriculture Hatch Funds (Project \#: LAB94230) covered some field trip costs. We thank the United States Geological Survey for making the river discharge data available for carbon flux estimation. The statements, findings and conclusions are those of the authors and do not necessarily reflect the views of the funding agencies. Thanks also go to Songjie He and Olivia Bramlett for their great help in field and laboratory assistance.

Author Contributions: Yi-Jun Xu conceived and designed the study; Emily Marie DelDuco performed the field sampling and measurements; Yi-Jun $\mathrm{Xu}$ and Emily Marie DelDuco analyzed the data and wrote the article. Both authors revised and proofread the manuscript for publication.

Conflicts of Interest: The authors declare no conflict of interest. 


\section{References}

1. Chavez, F.; Takahashi, T. Coastal oceans. In The First State of the Carbon Cycle Report (SOCCR): North American Carbon Budget and Implications for the Global Carbon Cycle; U.S. Climate Change Science Program and the Subcommittee on Global Change Research, National Ocean and Atmospheric Administration, Climate Program Office: Silver Spring, MD, USA, 2007; Chapter 15; pp. 83-92.

2. Tank, J.L.; Rosi-Marshall, E.J.; Griffiths, N.A.; Entrekin, S.A.; Stephen, M.L. A review of allochthonous organic matter dynamics and metabolism in streams. J. N. Am. Benthol. Soc. 2010, 29, 118-146. [CrossRef]

3. Bianchi, T.S.; Filley, T.; Dria, K.; Hatcher, P.G. Temporal variability in sources of dissolved organic carbon in the lower Mississippi river. Geochim. Cosmochim. Acta 2004, 68, 959-967. [CrossRef]

4. Bianchi, T.S.; Wysocki, L.A.; Stewart, M.; Filley, T.R.; McKee, B.A. Temporal variability in terrestrially-derived sources of particulate organic carbon in the lower Mississippi River and its upper tributaries. Geochim. Cosmochim. Acta 2007, 71, 4425-4437. [CrossRef]

5. Cai, Y.; Guo, L.; Douglas, T.A. Temporal variation in organic carbon species and fluxes from the Chena River, Alaska. Limnol. Oceanogr. 2008, 53, 1408-1419. [CrossRef]

6. Raymond, P.A.; Cole, J.J. Increase in the export of alkalinity from North America's largest river. Science 2003, 301, 88-91. [CrossRef] [PubMed]

7. Joshi, S.; Xu, Y.J. Assessment of suspended sand availability under different flow conditions of the Lowermost Mississippi River at Tarbert Landing during 1973-2013. Water 2015, 7. [CrossRef]

8. Rosen, T.; Xu, Y.J. Estimation of sedimentation rates in the distributary basin of the Mississippi River, the Atchafalaya River Basin, USA. Hydrol. Res. 2015, 46, 244-257. [CrossRef]

9. Donner, S.D.; Kucharik, C.J.; Foley, J.A. Impact of changing land use practices on nitrate export by the Mississippi River. Glob. Biogeochem. Cycles 2004, 18. [CrossRef]

10. Lohrenz, S.; Fahnensiel, G.L.; Redalje, D.G.; Lang, G.A.; Chen, X.; Dagg, M.J. Variations in primary production of northern Gulf of Mexico continental shelf waters linked to nutrient inputs from the Mississippi River. Mar. Ecol. Prog. Ser. 1997, 155, 45-54. [CrossRef]

11. Green, R.E.; Bianchi, T.S.; Dagg, M.J.; Walker, N.D.; Breed, G.A. An organic carbon budget for the Mississippi River turbidity plume and plume contributions to air-sea $\mathrm{CO}_{2}$ fluxes and bottom water hypoxia. Estuaries Coasts 2006, 29, 579-597. [CrossRef]

12. Justic, D.; Rabalais, N.N.; Turner, R.E. Impacts of climate change on net productivity of coastal waters: Implications for carbon budgets and hypoxia. Clim. Res. 1997, 8, 225-237. [CrossRef]

13. IPCC. Climate Change 2013: The Physical Science Basis. Contribution of Working Group I to the Fifth Assessment Report of the Intergovernmental Panel on Climate Change; Stocker, T.F., Qin, D., Plattner, G.-K., Tignor, M., Allen, S.K., Boschung, J., Nauels, A., Xia, Y., Bex, V., Midgley, P.M., Eds.; Cambridge University Press: Cambridge, UK; New York, NY, USA, 2013; p. 1535. [CrossRef]

14. Aufdenkampe, A.K.; Mayorga, E.; Raymond, P.A.; Melack, J.M.; Doney, S.C.; Alin, S.R.; Aalto, R.E.; Yoo, K. Riverine cofupling of biogeochemical cycles between land, oceans, and atmosphere. Front. Ecol. Environ. 2011, 9, 53-60. [CrossRef]

15. Xu, Y.J.; Bryant Mason, A. Determining the nitrate contribution of the Red River to the Atchafalaya River in the northern Gulf of Mexico under changing climate. In Water Quality: Current Trends and Expected Climate Change Impacts; IAHS Publication 348; Peters, J., Ed.; IAHS Publication: Wallingford, UK, 2011; pp. 95-100.

16. $\mathrm{Xu}, \mathrm{Y} . J$. Transport and retention of nitrogen, phosphorus and carbon in North America's largest river swamp basin, the Atchafalaya river basin. Water 2013, 5, 379-393. [CrossRef]

17. Benner, R.; Opsahl, S. Molecular indicators of the sources and transformations of dissolved organic matter in the Mississippi River plume. Organ. Geochem. 2001, 32, 597-611. [CrossRef]

18. Shen, Y.; Fichot, C.G.; Benner, R. Floodplain influence on dissolved organic matter composition and export from the Mississippi-Atchafalaya River system to the Gulf of Mexico. Limnol. Oceanogr. 2012, 57, 1149-1160. [CrossRef]

19. Ehleringer, J.R.; Cerling, T.E. C3 and C4 photosynthesis. In Encyclopedia of Global Environmental Change-Volume 2. the Earth System: Biological and Ecological Dimensions of Global Environmental Change; Mooney, H.A., Canadell, J.G., Eds.; John Wiley \& Sons, Ltd.: Chichester, UK, 2002; Volume 2, pp. 186-190. 
20. Mook, W.G.; Koopmans, M.; Carter, A.F.; Keeling, C.D. Seasonal, latitudinal, and secular variations in the abundance and isotopic ratios of atmospheric carbon dioxide: 1. Results from land stations. J. Geophys. Res. Oceans 1983, 88, 10915-10933. [CrossRef]

21. SaLomons, W.; Mook, W. Isotope geochemistry of carbonates in the weathering zone. In Handbook of Environmental Isotope Geochemistry; Elsevier: Amsterdam, the Netherlands, 1986; Volume 2, pp. 239-269.

22. O'Leary, M.H. Carbon isotopes in photosynthesis Fractionation techniques may reveal new aspects of carbon dynamics in plants. BioScience 1988, 38, 328-336. [CrossRef]

23. Vogel, J. Variability of carbon isotope fractionation during photosynthesis. In Stable Isotopes and Plant Carbon-Water Relations; Saugier, B., Ehleringer, J.R., Hall, A.E., Farquhar, G.D., Eds.; Academic Press Inc.: San Diego, CA, USA, 1993; pp. 29-46.

24. Baird, M.E.; Emsley, S.M.; McGlade, J.M. Using a phytoplankton growth model to predict the fractionation of stable carbon isotopes. J. Plankton Res. 2001, 23, 841-848. [CrossRef]

25. Dubois, K.D.; Lee, D.; Veizer, J. Isotopic constraints on alkalinity, dissolved organic carbon, and atmospheric carbon dioxide fluxes in the Mississippi River. J. Geophys. Res. Biogeosci. 2010, 115. [CrossRef]

26. Xu, Y.J. Total nitrogen inflow and outflow from a large river swamp basin to the Gulf of Mexico. Hydrol. Sci. J. 2006, 51, 531-542. [CrossRef]

27. U.S. Department of the Interior. Endrin pollution in the lower Mississippi River Basin. In Federal Water Pollution Control Administration; U.S. Department of the Interior: Dallas, TX, USA, 1969; p. 213.

28. Coplen, T.B. Guidelines and recommended terms for expression of stable-isotope-ratio and gas-ratio measurement results. Rapid Commun. Mass Spectrom. 2011, 25, 2538-2560. [CrossRef] [PubMed]

29. Cai, W.-J.; Wang, Y. The chemistry, fluxes, and sources of carbon dioxide in the estuarine waters of the Satilla and Altamaha Rivers, Georgia. Limnol. Oceanogr. 1998, 43, 657-668. [CrossRef]

30. Weiss, R.F. Carbon dioxide in water and seawater: The solubility of a non-ideal gas. Mar. Chem. 1974, 2, 203-215. [CrossRef]

31. Harned, H.S.; Davis, R. The ionization constant of carbonic acid in water and the solubility of carbon dioxide in water and aqueous salt solutions from 0 to 50 . J. Am. Chem. Soc. 1943, 65, 2030-2037. [CrossRef]

32. Harned, H.S.; Scholes, S.R., Jr. The ionization constant of $\mathrm{HCO}_{3}$ from 0 to 50. J. Am. Chem. Soc. 1941, 63, 1706-1709. [CrossRef]

33. Cerling, T.E.; Solomon, D.K.; Quade, J.; Bowman, J.R. On the isotopic composition of carbon in soil carbon dioxide. Geochim. Cosmochim. Acta 1991, 55, 3403-3405. [CrossRef]

34. Zhang, J.; Quay, P.; Wilbur, D. Carbon isotope fractionation during gas-water exchange and dissolution of $\mathrm{CO}_{2}$. Geochim. Cosmochim. Acta 1995, 59, 107-114. [CrossRef]

35. Matthews, W.J.; Vaughn, C.C.; Gido, K.B.; Marsh-Matthews, E. Southern plains rivers. In Rivers of North America; Benke, A.C., Cushing, C.E., Eds.; Elsevier Academic Press: Cambridge, MA, USA, 2005; pp. 283-325.

36. Osborne, C.P.; Salomaa, A.; Kluyver, T.A.; Visser, V.; Kellogg, E.A.; Morrone, O.; Vorontsova, M.S.; Clayton, W.D.; Simpson, D.A. A global database of C4 photosynthesis in grasses. New Phytol. 2014, 204, 441-446. [CrossRef] [PubMed]

37. Butman, D.E.; Wilson, H.F.; Barnes, R.T.; Xenopoulos, M.A.; Raymond, P.A. Increased mobilization of aged carbon to rivers by human disturbance. Nat. Geosci. 2015, 8, 112-116. [CrossRef]

38. Kiffney, P.M.; Richardson, J.S.; Feller, M.C. Fluvial and epilithic organic matter dynamics in headwater streams of southwestern British Columbia, Canada. Arch. Hydrobiol. 2000, 149, 109-129. [CrossRef]

39. Tian, H.; Ren, W.; Yang, J.; Tao, B.; Cai, W.-J.; Lohrenz, S.E.; Hopkinson, C.S.; Liu, M.; Yang, Q.; Lu, C.; Zhang, B.; Banger, K.; Pan, S.; He, R.; Xue, Z. Climate extremes dominating seasonal and interannual variations in carbon export from the Mississippi River basin. Glob. Biogeochem. Cycles 2015, 29, $1333-1347$. [CrossRef]

40. Wallace, J.B.; Whiles, M.R.; Eggert, S.; Cuffney, T.F.; Lugthart, G.J.; Chung, K. Long-term dynamics of coarse particulate organic matter in three Appalachian Mountain Streams. N. Am. Benthol. Soc. 1995, 14, $217-232$. [CrossRef]

41. Voss, B.M.; Wickland, K.P.; Aiken, G.R.; Striegl, R.G. Biological and land use controls on the isotopic composition of aquatic carbon in the Upper Mississippi River Basin. Glob. Biogeochem. Cycles 2017, 31, 1271-1288. [CrossRef] 
42. Iwata, T.; Suzuki, T.; Togashi, H.; Koiwa, N.; Shibata, H.; Urabe, J. Fluvial transport of carbon along the river-to-ocean continuum and its potential impacts on a brackish water food web in the Iwaki River watershed, northern Japan. Ecol. Res. 2013, 28, 703-716. [CrossRef]

43. Polsenaere, P.; Abril, G. Modelling $\mathrm{CO}_{2}$ degassing from small acidic rivers using water $\mathrm{pCO}_{2}, \mathrm{DIC}$ and $\delta^{13}$ C-DIC data. Geochim. Cosmochim. Acta 2012, 91, 220-239. [CrossRef]

44. Hartmann, D.L.; Klein Tank, A.M.G.; Rusticucci, M.; Alexander, L.V.; Brönnimann, S.; Charabi, Y.; Dentener, F.J.; Dlugokencky, E.J.; Easterling, D.R.; Kaplan, A.; Soden, B.J.; Thorne, P.W.; Wild, M.; Zhai, P.M. Observations: Atmosphere and surface. In Climate Change 2013: The Physical Science Basis Contribution of Working Group I to the Fifth Assessment Report of the Intergovernmental Panel on Climate Change; Stocker, T.F., Qin, D., Plattner, G.-K., Tignor, M., Allen, S.K., Boschung, J., Nauels, A., Xia, Y., Bex, V., Midgley, P.M., Eds.; Cambridge University Press: Cambridge, UK; New York, NY, USA, 2013.

45. Van Geldern, R.; Schulte, P.; Mader, M.; Baier, A.; Barth, J.A. Spatial and temporal variations of pCO2, dissolved inorganic carbon and stable isotopes along a temperate karstic watercourse. Hydrol. Process. 2015, 29, 3423-3440. [CrossRef]

46. Johnson, M.S.; Lehmann, J.; Riha, S.J.; Krusche, A.V.; Richey, J.E.; Ometto, J.P.H.B.; Couto, E.G. CO $\mathrm{CO}_{2}$ efflux from Amazonian headwater streams represents a significant fate for deep soil respiration. Geophys. Res. Lett. 2008, 35. [CrossRef]

47. Mayorga, E.; Aufdenkampe, A.K.; Masiello, C.A.; Krusche, A.V.; Hedges, J.I.; Quay, P.D.; Richey, J.E.; Brown, T.A. Young organic matter as a source of carbon dioxide outgassing from Amazonian rivers. Nature 2005, 436, 538-541. [CrossRef] [PubMed]

48. Schulte, P.; van Geldern, R.; Freitag, H.; Karim, A.; Négrel, P.; Petelet-Giraud, E.; Probst, A.; Probst, J.-L.; Telmer, K.; Veizer, J.; et al. Applications of stable water and carbon isotopes in watershed research: Weathering, carbon cycling, and water balances. Earth-Sci. Rev. 2011, 109, 20-31. [CrossRef]

49. Vuorio, K.; Meili, M.; Sarvala, J. Taxon-specific variation in the stable isotopic signatures ( $\delta 13 \mathrm{C}$ and $\delta 15 \mathrm{~N})$ of lake phytoplankton. Freshw. Biol. 2006, 51, 807-822. [CrossRef]

50. Holm-Hansen, O.; Lorenzen, C.J.; Holmes, R.W.; Strickland, J.D. Fluorometric determination of chlorophyll. ICES J. Mar. Sci. 1965, 30, 3-15. [CrossRef]

51. Gregor, J.; Maršálek, B. Freshwater phytoplankton quantification by chlorophyll $a$ : A comparative study of in vitro, in vivo and in situ methods. Water Res. 2004, 38, 517-522. [CrossRef] [PubMed]

52. Moss, B. Studies on the degradation of chlorophyll $a$ and carotenoids in freshwaters. New Phytol. 1968, 67, 49-59. [CrossRef]

53. Longing, D.; Haggard, B.E. Distributions of median nutrient and chlorophyll concentrations across the Red River Basin, USA. J. Environ. Qual. 2010, 39, 1966-1974. [CrossRef] [PubMed]

54. Cole, J.J.; Prairie, Y.T.; Caraco, N.F.; McDowell, W.H.; Tranvik, L.J.; Striegl, R.G.; Duarte, C.M.; Kortelainen, P.; Downing, J.A.; Middelburg, J.J.; Melack, J. Plumbing the Global Carbon Cycle: Integrating Inland Waters into the Terrestrial Carbon Budget. Ecosystems 2007, 10, 172-185. [CrossRef]

55. Catalan, N.; Marce, R.; Kothawala, D.N.; Tranvik, L.J. Organic carbon decomposition rates controlled by water retention time across inland waters. Nat. Geosci. 2016, 9, 501-504. [CrossRef]

56. Casas-Ruiz, J.P.; Catalán, N.; Gómez-Gener, L.; von Schiller, D.; Obrador, B.; Kothawala, D.N.; López, P.; Sabater, S.; Marcé, R. A tale of pipes and reactors: Controls on the in-stream dynamics of dissolved organic matter in rivers. Limnol. Oceanogr. 2017. [CrossRef]

(C) 2017 by the authors. Licensee MDPI, Basel, Switzerland. This article is an open access article distributed under the terms and conditions of the Creative Commons Attribution (CC BY) license (http://creativecommons.org/licenses/by/4.0/). 